\title{
KASTAVAC DR. FRAN MANDIĆ (1851. - 1924.), UGLEDNI LIJEČNIK I „HRVATSKI KONZUL“ U TRSTU
}

\author{
DR FRAN MANDIĆ (1851 - 1924): \\ A REPUTED PHYSICIAN FROM KASTAV \\ AND “CROATIAN CONSUL” IN TRIESTE
}

\author{
Ivica Vučak*
}

\begin{abstract}
SuMMARY
Born in Istria, then part of the Austro-Hungarian Empire, Fran Mandić (1851-1924) finished a Croatian grammar school in Rijeka and studied medicine in Graz, Austria and in Prague, Bohemia. After graduation, he settled in Trieste, a major Austrian port, where he spent his entire career. After a period in the State Hospital in Trieste, Mandić ran his own practice and held a position of medical adviser of the Austrian State Railway in Istria. Since his student days, he had championed equal political rights for the Croatian people in Istria. Aware of the importance of education, he donated his time and money for a number of new schools to open throughout Istria. For his merits he received high honours from the Emperor and an honorary Citizenship of Opatija, but the greatest recognition was the respect he earned from his patients and their families.
\end{abstract}

Keywords: Medicine, history of medicine, Istria, Croatia, Trieste, Slovenia, AustroHungarian Monarchy, Italy

\section{UvoD}

U knjizi Znameniti i zaslužni Hrvati te pomena vrijedna lica u hrvatskoj povijesti od 925. -I925. tiskanoj u Zagrebu u prigodi obilježavanja tisućljeća

\footnotetext{
Adresa za dopisivanje: Ivica Vučak, Hrvatsko društvo za povijest medicine Hrvatskog liječničkog zbora, Šubićeva 9, 10000 Zagreb. E-pošta: ivica.vucak@gmail.com.
} 
hrvatskoga kraljevstva, objavljeni su životopisi mnogih koji su „doprinijeli svoj kamečak velebnoj zgradi hrvatske slave“. U njoj sam našao književnika dr. Dragutina Ćepulića (I893. - I976.), ali ne i njegova brata liječnika dr. Vladimira Ćepulića (I89I. - I964.) koji je bio voditelj Odjela za tuberkulozne bolesnike u zagrebačkoj Zakladnoj bolnici (I920.), utemeljitelj i ravnatelj Škole za sestre (I92I.) te šef prvoga Antituberkuloznog dispanzera u Zagrebu (I921.), a bio je i ekspert Međunarodne unije za borbu protiv tuberkuloze te marljivi sudionik u aktivnostima Hrvatskoga liječničkog zbora. Stoga me je zaintrigiralo kada sam uz uglednog borca za prava Hrvata u Istri prof. Matka Mandića (I849. - I915.), svećenika, dugogodišnjeg urednika Naše Sloge i zastupnika u Zemaljskom saboru Istre te u Carevinskom vijeću u Beču, pronašao i članak o njegovu bratu liječniku dr. Franji Mandiću, koji je potpisao Velimir Deželić sin (I888. - I976.). ${ }^{1}$ U raspravama o povijesti političkih borbi Hrvata u Istri nezaobilazno je mjesto "hrvatskog konzula" u Trstu Matka Mandića, dijela trolista Spinčić-Mandić-Laginja, a ovaj je članak pokušaj osvjetljavanja života i rada zaboravljenoga dr. Frana Mandića.

\section{Djetinjstvo}

Rođen je 22. ožujka I85ı. u Rukavcu/Mihotićima u Kastavštini u obitelji Mate Mandića (I815. - I885.) i Marije rođ. Dubrović. Imao je dva brata i dvije sestre, Katarinu i Mariju, koje su ostale kod kuće i udale se za Brnčića i Mavrovića. Prva tri razreda pučke škole završio je u Rukavcu, a poučavao ga je kapelan Josip Janc (r820. - I89r.) rodom iz Begna u Kranjskoj. ${ }^{2}$ Četvrti je razred pohađao u Kastvu, u jedinoj četverorazrednoj školi u Istri u kojoj ga je od I859. do I862. poučavao Fran Ravnik (I832. - I883.), kapelan u župi sv. Jelene u Kastvu. ${ }^{3}$

Najstariji brat Ivan (1839. - 1902.) postao je pomorac. Drugi brat Matko započeo je gimnaziju u Pazinu, nastavio u Senju, a završio u Rijeci. Nakon ispita zrelosti 1870., započeo je studij bogoslovije u Gorici slijedeći primjer njihova ujaka Matije Dubrovića (I808. - I882.), dugogodišnjeg župnika u Trstu. ${ }^{4}$

Fran Mandić slijedio je svoga brata te školske godine 1870./187r. i završio osmi razred u Rijeci. Razrednik mu je bio Tadija Smičiklas (I843. - I9I4.) koji će poslije postati profesor i dekan Mudroslovnog fakulteta u Zagrebu, rektor

1 Laszowski, E. Ed. (1925), Znameniti i zaslužni Hrvati te pomena vrijedna lica u hrvatskoj povijesti od 925-1925., Zagreb, str. 172.

Josip Janc. Naša sloga, br. 53, 31. 12. 1891., 3.

Naša sloga br. 3, 17. 1. 1884., 1.

Naša sloga br. $4,16.2$. 1882., 3 . 
Sveučilišta, član Akademije i Matice hrvatske te predsjednik obiju institucija. Nakon usmenog dijela ispita zrelosti 17. kolovoza 187I., Franjo Mandić ocijenjen je "zrelim".

\section{StUdij MEdicine}

Odabravši liječništvo kao svoje buduće zanimanje, Fran Mandić je ujesen I87I. započeo studij medicine u Grazu. Isto je učinio i njegov suškolarac dvadesetogodišnji Dragutin Forenbacher (I850. - I895.), rodom iz Fužina, a devetnaestogodišnji je Matko Laginja (I852. - 1930.) ocijenjen, jedini u razredu, "zrelim s odlikom", počeo studij na Pravoslovnoj akademiji u Zagrebu. ${ }^{5}$ Poslije je i on nastavio studirati na Pravnom fakultetu u Grazu. Uz studentske obveze, zanimali su se i za društvena zbivanja. "Mi mlađi vaši koji smo doprli do visokih škola, a nismo do sad zatajili materinskog mleka niti ga ikada zatajismo, mi koji se ne damo više slepiti, jer su nam oči knjige otvorile, mi od svoje strane upravljamo glas na onu trojicu gospode koja u Beču sede, navlastito na gospodina Polesina, zastupnika pučkih općina zapadne Istre - opominjemo ih da ima u Istri 180.000 Hrvata, s kojima se dosad nije računalo, ali od sada neće svaki račun bez njih proći. Mi kao buduća inteligencija narodna u Istri najsvečanije protestujemo proti svakom glasu koji bi se u Beču podigao za nehrvatsku gimnaziju u Pazinu, na očiti zator naše hrvatske narodnosti i našega moralnoga razvitka", pisalo je u proglasu Hrvatskom narodu po Istri i Otocih, potpisanom u prosincu 1873. i objavljenome u novogodišnjem broju Naše Sloge i874. godine. ${ }^{6}$ To je bio prosvjed mladih intelektualaca, redom pravaša, protiv talijanske gimnazije u Pazinu. Ime medicinara Franje Mandića bilo je odmah iza prvopotpisanog studenta prava Laginje na popisu trideset šest Istrana akademičara. I njegov brat Matko Mandić, tada bogoslov u Gorici, bio je među supotpisnicima. Krajem ožujka i874. Frane Mandić bio je među utemeljiteljima Društva Bratovšćina hrvatskih ljudi za Istru?. Uz Matka Laginju i studenta filozofije Vjekoslava Spinčića (I848. - 1933.) supotpisnik je Proglasa hrvatskom narodu i svakomu prijatelju pučkoga napredka u kojem su objasnili "zašto se hrvatski narod u Istri jedva kao malo diete oda sna budi, a ne žive život naroda dostojan odlučili smo osnovati društvo 'Bratovšćina hrvatskih ljudi u Istri'“. Temeljna je aktivnost Bratovšćine bila prikupljanje sredstava za školovanje mladih siromašnih Istrana, a priloge su primali osnivački

5 Vučak I. (2009), Počeci hrvatske psihijatrije i dr. Dragutin Forenbacher. Liječničke novine br. 77, 15. 3. 2009., 66-70.

6 Naša sloga br. 1, 1. 1. 1874., 1-2.

7 Primorac br. 32, 22. 4. 1874., 3. 
odbor Bratovšćine u Kastvu te uredništvo Naše Sloge u Trstu. Medicinar Franjo Mandić u Grazu darovao je dvije forinte i tako bio među prvima u Imeniku članova društva ${ }^{8}$. Nakon tri godine u Grazu Franjo Mandić je od zimskog semestra I874./1875. nastavio studij medicine na sveučilištu Karla Ferdinanda u Pragu. Vjerojatno je to bilo povezano s odlaskom njegova brata Matka, nakon završetka studija bogoslovije i zaređivanja i874. u Trstu, u Prag na studij prirodnih znanosti na tamošnjem Filozofskom fakultetu u sporazumu s biskupom Jurjem Dobrilom (I8I2. - I882.), mecenom i narodnim preporoditeljem. Iz Praga je potkraj 1876. medicinar Franjo Mandić uplatio jednu forintu prinosa za Bratovšćinu hrvatskih ljudi u Istri. ${ }^{9}$ Nakon uspješno položenih ispita Franjo Mandić iz Kastva je u četvrtak 21. prosinca I876. u Pragu ,javno promoviran za doktora sveg liječništva" ${ }^{\text {“10. }}$.

\section{TRST}

Vratio se u Trst i u siječnju I877. započeo službu kao pomoćnik na trećem internom odjelu u Gradskoj bolnici. Već u listopadu te godine imenovan je sekundarnim liječnikom Gradske bolnice. Od 55 novoprimljenog bolesnika u bolnicu u Trstu tijekom studenoga I877., ozravila su 444, umrlo $87^{11}$. Uz 742 bolesnika preostala na liječenju ( 375 muških i 367 ženskih), bilo ih je još I2O nevoljnih u ludnici ( 67 muških i 53 žena) te 65 djece u sirotištu (uz 4 I dojkinju).

Krajem srpnja 1878. Austro-Ugarska je, prema zaključcima Berlinskog kongresa europskih velevlasti, okupirala Bosnu i Hercegovinu. Fran Mandić morao je prekinuti bolnički staž jer je bio unovačen u vojničku službu. Vijest o "imenovanju vojničkog liječnika u Bosni dr. Frana Mandića (iz Rukavca) za pukovnijskog liječnika prvog reda" prenijela je tršćanska Naša Sloga iz hrvatskih novina u rujnu I878., uz komentar: "A jedva su dvije godine da je svršio nauke! Najsrdačnije Ti Frane svi čestitamo! Sretno nam se proslavljen povratio!" 12 No ta se vijest zapravo odnosila na pukovnijskog liječnika u Trstu dr. Šimu Mandića (I839. - I920.), rodom iz Boljuna u Istri, koji je I86o. završio gimnaziju u Rijeci, prvi iz Istre preko Učke ${ }^{13}$. Vojnički liječnici dr. Franjo Mandić i dr. Nikola Ivanović, kapetan 46. regimente, podijelili su u ožujku I879. u Travniku darove djeci za uspjeh postignut u učenju ${ }^{14}$.

\footnotetext{
Naša sloga br. 13, 1. 7. 1874., 3.

Naša sloga br. 4, 16. 2. 1877., 4.

Obzor br. 6, 9. 1. 1877., 3 .

Naša sloga br. 24, 16. 12. 1877., 3.

Naša sloga br. 19, 1. 10. 1878., 4.

Naša sloga br. 21, 1. 11. 1878., 4.

Obzor br. 2, 11. 3. 1879., 2.
} 


\section{PRIVATNA PRAKSA}

Po povratku iz rata dr. Frano Mandić bio je praktični liječnik u Trstu, a potkraj 198r. imenovan je pričuvnim pukovnijskim liječnikom i dodijeljen „vojničkom špitalu u Ljubljani“. ${ }^{15} \mathrm{Od}$ I. veljače I883. njegov je brat Matko, po pozivu hrvatskih prvaka u Istri, preuzeo mjesto urednika Naše Sloge. Dr. Mandić je u Trstu predstavljao adresu na koju su se mogli obratiti Hrvati koji su tu živjeli, ali i svi drugi kojima je u Trstu bila potrebna medicinska pomoć. "Obratite se dr Franu Mandiću, Via Malcanton No 2 ili dr. Andriji Longino (Ospedale civico)", poručio je u lipnju i884. urednik Našse Sloge g. Stjepanu Sućurcu. ${ }^{16}$ Poslije je dr. Mandić preselio svoju ordinaciju iz Ulice Malcanton na Piazza della Borsa br. $13^{17}$. U kolovozu I894. preselio je s Piazza della Borsa natrag u Ulicu Malcanton br. 8/II ${ }^{18}$, da bi 24. kolovoza I895. ponovno iz Ulice Malcanton preselio na Piazza della Borsa broj I2/II, uza samu kuću u kojoj je stanovao prije dvije godine. ${ }^{19}$

"Ako liečnik iz svršenih nauka ne njeguje knjigu, ubrzo će dokazati da je silno u znanosti zaostao. Njegova struka danomice napreduje pa ne ide li uzastopce sa njezinim napretkom, zaostaje na način da od 'likara' može spasti na 'bikara' i pučki učitelj ne može nikako ustvrditi iza obvezatnih nauka, da je dovoljno naobražen i da mu više ne treba učiti. Znanje što ga je pribavio u školi jest tek početak; naobrazba prisvojena na učiteljištu jest tek temelj, na kojemu mora neprestano dalje graditi te se usavršavati u općem, ali najviše u stručnom znanju...", razmišljali su dr. Mandić i brat mu Matko. ${ }^{20}$

O ugledu koji je dr. Fran Mandić uživao barem djelomična slika može se dobiti na temelju zabilješki u onodobnim novinama. Teško oboljelog potpredsjednika Zemaljskog sabora u Poreču dr. Antuna Dukića (I854. - I894.), odvjetnika i načelnika u Pazinu, njegovala su dvojica domaćih vrsnih liječnika, a u utorak I5. prosinca I89o. posjetio ga je njegov osobni prijatelj i liječnik dr. Fran Mandić iz Trsta koji se nadao da će bolesnik "preboljeti grdnu bolest ne nadođu li kakvi novi zapletaji”"1. Povoljna prognoza dr. Mandića se ostvarila te je "pogibeljna bolest dr. Dukića krenula na bolje"22. Nadžupnik

Naša sloga br. 24, 16. 12. 1881., 3.

6 Naša sloga br. 26, 26. 6. 1884., 6. Listnica uredničtva.

17 Naša sloga br. 36, 2. 9. 188., 3. Bolestnike prima 3-4 popodne. Toliko na znanje onima koje bi to moglo zanimati.

18 Naša sloga br. 35, 30. 8. 1894., 3.

19 Naša sloga br. 35, 22. 8. 1895., 2. Promjena stana. Ovoliko na znanje onim koji bi trebali njegovu pomoć.

20 Naša sloga br. 24, 15. 6. 1893., 3. Potpomognimo što je naše.

21 Naša sloga br. 51, 17. 12. 1890., 3.

22 Naša sloga br. 1, 1. 1. 1891., 3. 
u Karkavcu Jakov Ladavac zahvalio je 20. lipnja i892. dr. Franu Mandiću koji je "vještačkom baš rukom moju bolest uprav usried srca pogodio te tim mene iz najveće pogibelji izbavio"23. Župnik-dekan u Podgradu Antun Rogač obolio je u svibnju i893. na plućima, a njegovi su zabrinuti prijatelji „u skrajnoj nevolji“ brzojavno pozvali dr. Frana Mandića, liječnika u Trstu. Odmah se odazvao pozivu, "našao bolesnika zbilja u pogibeljnom stanju“, no uz njegovo liječničko znanje i hvalevrijedno zauzimanje stanje bolesnika se popravilo. "Nakon bolovanja od preko mjesec dana posve je izvan pogibelji. Ustao je i nada se za koji dan opet misiti. "' "Svi župljani hvale Svevišnjega što im je na životu uzdržao miloga pastira, a mi koji smo župniku u samoj blizini, uz tu hvalu, izričemo i drugu našemu, rodoljubu i vriednom liečniku g. Mandiću." U prigodi smrti Marije Mandić, supruge rodoljubivoga gospodina Frana Mandića, posjednika u Rošićima (Kućele), bivšeg općinskog zastupnika i župana, koja je pokopana tik pred Božić I899. u Kastvu, njezin je suprug javno zahvalio na prvome mjestu "veleučenom liečniku dr. Franu Mandiću, dr. Šebesti i dr. Daboviću koji su uložili svu liečničku vještinu ne bi li meni i mojoj djeci pokojnicu sačuvali te našemu rođaku g. Matku Mandiću koji ju je do zadnjega počitka dopratio" ${ }^{25}$. Ivana Podreka umrla je u Trstu 7. prosinca 1900., a njezin suprug i sin posebno su zahvalili "veleučenom gosp. Dr. Franu Mandiću koji je na osobito požrtvovan način nastojao da uzdrži našoj ljubavi premilu pokojnicu" ${ }^{26}$. U Trstu je 17. rujna 190I. umro biskup tršćansko-koparski Andrija Marija Šterk (I827. - I9or.) koji se u pitanjima zdravlja savjetovao s dr. Franom Mandićem otkako je u kolovozu i88o. imenovan kanonikom prvostolne crkve u Trstu. ${ }^{27} \mathrm{U}$ travnju i884. bio je Šterk "vezan za postelju dulje od mjesec dana zbog upale podrebrice (pleuritisa), a podigao se tek na dan Uskrsa nakon što mu je to njegov liječnik dr. M. dopustio"28. Dr. Mandić je pratio obdukciju svoga dugogodišnjega pacijenta koju je obavio dr. Šime Pertot (1845. - 1907.) te pomogao pri balzamiranju. ${ }^{29}$ Šterk je pokopan na tršćanskom groblju sv. Ane između biskupa Dobrile i župnika Dubrovića, ujaka dr. Mandića. Ljekarnik Petar Karabaić, sinovac monsignora Antuna Karabaića (1832. - I906.), prvog urednika Naše sloge koji je preminuo u Trstu

\footnotetext{
Naša sloga br. 25, 23. 6. 1892., 4.

Naša sloga br. 22, 8. 6. 1893., 3.

Naša sloga br. 45, 28. 12. 1899., 3-4.

Naša sloga br. 85, 11. 12. 1900., 3 .

Naša sloga br. 74, 20. 9. 1901., 1; br. 16, 16. 8. 1880., 3.

Naša sloga br. 16, 17. 4. 1884,. 3.

Naša sloga br. 76, 27. 9. 1901., 3.
} 
22. siječnja igo6., zahvalio se u ime obitelji dr. Mandiću "koji se tečajem mnogo godina skrbno zauzimao za zdravlje"30.

\section{SAVJETNIK KOD DRŽAVNIH ŽELJEZNICA}

Dr. Fran Mandić bio je imenovan zdravstvenim savjetnikom Državnih željeznica sa sjedištem u Trstu. Bio je to važan i odgovoran posao, no u onodobnim istarskim prilikama, katkad i opasan. I893. Državno je odvjetništvo zaplijenilo Našu Slogu br. 33 od I7. kolovoza, a prema obavijesti u drugom izdanju razlog zapljeni bila je vijest o napadu na dr. Frana Mandića prigodom njegova službenog putovanja u Pazin 9. kolovoza I893. kao zdravstvenog savjetnika (konzulenta) Državnih željeznica. ${ }^{31} \mathrm{O}$ napadu na dr. Mandića oštrije i odlučnije pisale su najuvaženije hrvatsko-slovenske i njemačke novine u Trstu. ${ }^{32}$ Protiv izgrednika koji su "grdili, psovali i izviždali" dr. Frana Mandića održana je kod Općine u Pazinu 29. rujna I893. glavna kaznena rasprava. ${ }^{33}$ Devet napadača osuđeno je na globu od deset forinti (ili u slučaju neutuživosti na 48 sati zatvora). Jedan od problema s kojima su se željeznice u Istri suočavale, i koje je kao svoju zadaću morao rješavati dr. Mandić, bila je malarija. To je bilo vrijeme u kojem je problem malarije na Brijunskom otočju i obali Istre nasuprot njih rješavao dr. Robert Koch (I843. - I9Io.), a zatim dr. Otto Lenz (I872. - I959.) na zahtjev vlasnika otoka Paula Kupelwiesera (I843. - I9I9.). ${ }^{34} \mathrm{O}$ naporima na eradikaciji malarije na području Tršćanske željezničke direkcije objavio je dr. Mandić članak u lipanjskom broju časopisa Zeitschrift für Eisenbahnhigijene 1906 . godine ${ }^{35}$. Pohvalio se tehničkim rješenjima koja je smatrao zaslužnima za bolje rezulteta postignute u Istri (pruge Kanfanar - Rovinj, Divača - Pula) u usporedbi s onima u Dalmaciji uz prugu Slivno - Perković - Šibenik, odnosno Knin - Split.

\footnotetext{
Naša sloga br. 6, 8. 2. 1906., 4.

Naša sloga br. 33, 17. 8. 1893., 2.

Naša sloga br 34, 24. 8. 1893., 2.

Naša sloga br. 40, 5. 10. 1893., 3.

34 Vučak I. (2010), Otto Lenz i suzbijanje malarije na Brijunima. Liječničke novine br. 93, 15.10.2010, 56-9.

35 Mandić F. (1906), Malariatilgung im Gebiete der k.k. Staatsbahndirektion Triest, Zeitschrift für Eisenbahnhigiene, 2 (6), 145-163.
} 


\section{DRUŠTVENI ANGAŽMAN}

Dr. Mandić je bio redoviti pretplatnik Naše Sloge, a nekoliko je puta njegovo ime bilo u popisu prinosnika priloga za Našu Slogu. ${ }^{36,37,38}$ Objavio je i dva članka. "U oktobru prošle godine bio sam u Kastavšćini gdje sam doznao da se na Munah Škarlatina i Difteritis uvelike raširili. Mune leže kakva tri sata nad Kastavšćinom, a treći dan poslije mojega boravljenja imadoh priliku osvjedočiti se da se bolest jur i u Kastavšćini reć bi munjevitom brzinom razgranila. Sasma naravski, uz pomanjkanje strogih zdravstvenih naredbi u selima, pošast se nije mogla ovdje zaustaviti, već se je kako čujem otvorenim vratima razlila u obližnje Volosko, Rijeku i Lovran“, napisao je dr. Mandić početkom I882. u uvodu višedjelnoga članka o difteriji ${ }^{39}$. Bio je veoma skrupulozan; "nije tako lahko napisati štogod valjana o medicini za prosti narod; već sam predmet nije prikladan za prosto tumačenje, a kad bi to i izvedivo bilo, kod one konzervativne naravi i praznovjerja koje vlada $\mathrm{u}$ svem i svačem u našem narodu - pripovjedaj mu ti jedan put samo što je Difteritis, koliko je pogibeljna i kako se je imade čuvat, a on će ipak uz sav tvoj napor tražit svoje Jelice i Marice da mu uroke razvrgavaju ili moriće da mu gušćer taru i božje molitvice nabrajaju. Gospode svećenika i pučkih učitelja mislim je zadaća, da narod više put o stvari poduče, stare predsude i čarobije iz nje iztrijebe; dok ovo ne bude narod će po svojem: Kako je radio moj djed i moj otac, radim i ja." Nakon što je u r. i 3. broju r882. objavljen članak dr. Mandića Difteritis, objavljen je i kratki tekst o liječenju te bolesti prema metodi dr. Fielda iz Trsta. ${ }^{40}$ Ponovno se javio na stranicama Naše sloge početkom i884. godine. U prva dva broja u siječnju i884. objavio je tekst o povijesnom razvitku „zdravoslovja“, tj. higijene..$^{41}$ Obuhvatio je samo medicinu antiknog razdoblja, najavio i nastavak koji se, međutim, nije realizirao. Nastavio je sudjelovati u općenarodnoj skrbi za školovanje mladih istarskih Hrvata, započeto već u studentskim danima. U prigodi srebrnog pira carskog para Franje Josipa i Elizabete na Jurjevdan 24. travnja I879., urednik Naše Sloge predložio je stvaranje zaklade Kraljev pir te prikupljeni novac namijenio Bratovšćini hrvatskih ljudi u Istri. S jednom forintom prinosa odazvao se dr. Mandić, među prvima u Trstu. ${ }^{42}$ I sljedećih je godina nastavio redovito

36 Naša sloga br. 2, 9.1.1890., 4.

37 Naša sloga br. 13, 31. 3. 1898., 3.

38 Naša sloga br. 8, 19. 2. 1903., 8.

39 Mandić F. Difteritis. Naša sloga br. 1, 1. 1. 1882., 1; br. 3, 1. 2. 1882., 1.

40 Naša sloga br. 14, 16. 7. 1882., 4.

41 Mandić F. Poviest i razvitak zdravoslovja /Hygiene/. Naša sloga br. 1, 3. 1. 1884., 1-2; br. 2 , 10. 1. 1884., 2.

42 Naša sloga br. 7, 1. 4. 1879., 1; br. 11, 1. 6. 1879., 3. 
prinositi za Bratovšćinu hrvatskih ljudi u Istri, a povremeno je i aktivno sudjelovao na glavnim skupštinama Bratovšcine održavanim u Kastvu. ${ }^{43,44,45}$ U ožujku i885. pristupio je Bratovšćini hrvatskih ljudi u Istri kao utemeljitelj s prinosom od 25 forinti. ${ }^{46}$ Bio je jedan od četiri nova člana utemeljitelja, od ukupno trideset devet, koliko ih je pristupilo do listopada $1885 .{ }^{52}$ Cjelokupnu utemeljiteljnu svotu uplatio je do glavne skupštine u Kastvu 3. listopada I887. ${ }^{47}$ Sljedećih je godina prigodom božićnih i novogodišnjih blagdana redovito darivao dvije forinte Bratovšćini i tako se otkupio od čestitanja prijateljima i rodbini. ${ }^{48} \mathrm{U}$ veljači 1882. izabran je u odbor Slavjanske narodne čitaonice u Trstu te ponovno 31. prosinca $1882 .{ }^{49}$ Ustanovljena 29. siječnja i otvorena 9. ožujka I86r., Čitaonica je okupljala Slovence, Hrvate, Srbe, Crnogorce, Čehe i Slovake u Trstu. Ples Čitaonice organiziran 4. veljače I882. posjetio je i ruski konzul u Trstu. Na redovitoj glavnoj skupštini u Trstu I. siječnja I885. dr. Mandić izabran je za predsjednika Odbora Slavjanske čitaonice u Trstu. ${ }^{50}$ Dužnost predsjednika obnašao je do godišnje skupštine održane i7. siječnja I886., na kojoj je zaključeno da je Društvo tijekom I885. "lijepo napredovalo moralno i materijalno" ${ }^{51}$. I sljedećih je godina bio aktivan kao odbornik ili zamjenik odbornika. ${ }^{52}$ Pomagao je i rad Đačkoga pripomoćnog društva učenika hrvatske gimnazije u Pazinu, utemeljenoga I899. Početkom ožujka I9oo. darovao je Ioo kruna u počast uspomene na preminulog sina svoga kolege dr. Egydtasa Welponera (I849. - I933.), profesora porodiljstva u Trstu. ${ }^{53} \mathrm{U}$ svibnju I902. sjetio se toga Društva darom od 20 kruna kao uspomenom na svoga pokojnog brata Ivana, a zatim u lipnju 1902. u prigodi smrti Natalije Truden, dobrotvorke siromašne slovenske školske mladeži u Trstu (Io kruna) te prigodom smrti Franice Mačak rođene Noll (ro kruna). ${ }^{54}$ Dar Đačkome pripomoćnom društvu u Pazinu stizao je od dr. Frana Mandića za "oprost od čestitanja

\footnotetext{
Naša sloga br. 21, 1. 11. 1880., 3.

Naša sloga br. 42, 15. 10. 1885., 1-2.

Naša sloga br. 51, 20. 12. 1888., 1.

Naša sloga br. 13, 26. 3. 1885., 3.

Naša sloga br. 42, 20. 10. 1887., 1.
}

48 Naša sloga br. 52, 27. 12. 1888., 3; br. 52, 24. 12. 1889., 3; br. 51, 17. 12. 1890., 3; br. 53, 31. 12. 1891., 3; br. 52, 29. 12. 1892., 2; br. 3, 21. 1. 1897., 3; br. 4, 2. 2. 1899., 3; br. 7, 13. 2. 1908., 3; Riječki novi list br. 9, 11. 1. 1912., 1.

Naša sloga br. 2, 8. 1. 1885., 3 .

Naša sloga br. 3, 17. 1. 1886., 2-3.

Naša sloga br. 18, 5. 5. 1892., 3; br. 20, 15. 5. 1890., 2.

Naša sloga br. 10, 8. 3. 1900., 4.

Naša sloga br. 39, 23. 5. 1902., 4; br. 58, 29. 7. 1902., 4. 
božićnih i novogodišnjih blagdana ${ }^{55}$. C. i k. namjesništvo je 24 . veljače 1893 . odobrilo pravila udruge za razvitak hrvatskog i slovenskog školstva u Istri "na narodno-katoličkom temelju" pa se taj datum smatra danom utemeljenja Družbe sv. Ćirila i Metoda za Istru sa sjedištem u Puli. Prvi predsjednik bio je dr. Dinko Trinajstić (1858. - 1939.), od I894. do I9or. dr. Dinko Vitezić (1822. 1904.), a nakon njega prof. Vjekoslav Spinčić. Dr. Mandić je bio među onima koji su i redovitim prinosima Družbi, umjesto čestitanja božićnih i novogodišnjih blagdana, iskazivali svoje domoljublje. ${ }^{56}$ Prigodom jedne Akademije Hrvatskog društva Strossmayer u Trstu, dr. Fran Mandić preplatio je ulaznice s 20 kruna. ${ }^{57}$

Dr. Mandić bio je među zastupnicima slavenskih društava u Trstu izabranima u lipnju I882. u odbor ustrojen radi prikupljanja pomoći za podizanje Narodnog doma u Ljubljani ${ }^{58}$. U prigodi smrti Viktora Dolenca (I84I. - I887.), vlasnika tiskare, predsjednika Delavskoga potpornog društva, potpredsjednika političkog društva Edinost, staroste tršćanskog Sokola te urednika lista Edinost, od posljedica moždanog udara 20. srpnja i887. u Trstu, ustrojen je Odbor za prikupljanje dobrovoljnih prinosa za izgradnju spomenika..$^{59}$ Do 3. kolovoza I877. prikupljeno je 588 forinti, a dr. Mandić je preko Naše Sloge darovao Io forinti. ${ }^{60} \mathrm{Na}$ Uskrs, I4. travnja I895., Ljubljana je doživjela katastrofalan potres, a dr. Mandić je u Trstu, s io forinti, bio prvi na popisu prinosnika za Ljubljančane unesrećene potresom. ${ }^{61}$

\section{(NeUspješAn) izlet u POLITIKu}

Na izborima za zastupnika istarskih gradova u Državnom saboru u Beču, održanim 2. lipnja i885., vođe istarskih Hrvata i Slovenaca bili su svjesni da "U današnjim okolnostima teško da ćemo uspjeti sa novim kandidatima u gradovma, ali moramo i tu pokazati da smo pripravni na borbu da bi i u gradovima mogli prodrieti kad bi se okolnosti bar unekoliko promijenile" ${ }^{62}$. Stoga su političko društvo Edinost i Naša Sloga u ime slavenskog stanovništva kao svoga kandidata postavili dr. Frana Mandića, nasuprot

55 Naša sloga br. 102, 31. 12. 1901., 4; br. 13, 26. 3. 1903., 7; br. 1, 7. 1. 1904., 2; br. 1, 4. 1. 1906. , 3; br. 9, 25. 2. 1909., 2.

56 Naša sloga br. 2, 7. 1. 1909., 2; br. 5, 25. 1. 1909., 3; br. 4, 28. 1. 1915., 3; Riječki novi list br. 42, 18. 2. 1912., 1.

57 Riječki novi list br. 57, 7. 3. 1912., 1-2.

58 Naša sloga br. 13, 1. 7. 1882., 2.

59 Naša sloga br. 29, 21. 7. 1887., 2; br. 30, 28. 7. 1887., 3.

60 Naša sloga br. 31, 4. 8. 1887., 3.

61 Naša sloga br. 19, 2. 5. 1895., 2.

62 Naša sloga br. 22, 28. 5. 1885., 2. 
iskusnom političaru, predstavniku istarskih Talijana, rođenom Lošinjaninu, dr. Francescu Vidulichu (I8I9. - I889.) ${ }^{63}$. Očekivano, dr. Mandić nije prošao jer je "za Vidulicha dignuto što je imalo pravo glasa", no 450 glasova kojima je dr. Mandić javno zahvalio bio je znak buđenja istarskih Hrvata i opravdanje ocjene Eppur si muove. ${ }^{64} \mathrm{Za} \mathrm{dr}$. Mandića svoj je glas dalo $\mathrm{r} 80$ izbornika u Buzetu, u Pazinu njih ıoo, a u tim gradovima dr. Vidulich je dobio 86, odnosno 7r glas. ${ }^{65} \mathrm{Od} 200$ izbornika u gradu Kopru, I9o bilo je za Vidulicha, a deset za dr. Mandića. ${ }^{66}$ "Bar trećina izbornika bili su carsko-kraljevski službenici kapitanata, suda, carinarnice, kaznionice, gimnazije i slično. Neki hoće da se na njih nije utjecalo. Da je svakomu bilo slobodno glasovati po svojoj glavi. Dr. Vidulić je bio kandidat društva 'Società politica istriana', kandidat društva koje hoće uzdržati i širiti talijanstvo u Istri; Dr. Mandić je bio kandidat 'Edinosti' i 'Naše Sloge' koje štite Slavene Istre. Iz toga bi se zaključilo da su c. kr. službenici poduprli kandidata prvoimenovanoga društva, talijanizirajućeg. Ako pak se njim namignulo koga da izabiru, ako je istina što veli 'L'Istria' da su časnici kraljevske mornarice dobili nalog da glasuju za dr. Vidulicha, tad su ne pojedinci, nego oblasti radile za kandidata toga društva."

\section{Priznanja}

Krajem lipnja I894., na svršetku školske godine, dr. Mandić doputovao je iz Trsta po svoja dva sina, učenike hrvatske gimnazije u Rijeci. "Tom je prigodom boravio u Kastvu posjetivši u rodnoj kući majku te rođake i prijatelje. Mnogi Istrani, a osobito oni koji nisu posve zdravi propitivali su se o danu njegova dolaska da traže lieka za se ili za svoje. Ovdješnji ljudi poštuju i ciene i svoga općinskoga liečnika i druge koji na Voloskom ili u Rijeci, ali poštuju i ciene osobitim načinom, imadu veliko pouzdanje u lječnika doktora Frana Mandića. Još niti ne odpočine pod rođenim krovom, već vrve ljudi k njemu sa svih strana; jedva se kamo po Kastavšćini makne, već mu se prikazuju ljudi koji ga žele popitati za pomoć u njihovih bolesti. On dođe da odahne od svakodnevnoga napora, ali mu to u Kastavšćini nije moguće. Mjesto da otpočine, on valja da pretražuje stare i mlade, odrasle i djecu, muške i ženske i da im propisuje liekove. Rađe bi počivao, al opet ne može odbijati ljude koji imaju u njega toliko povjerenje, među kojima je rođen i dielomice odrastao. Često sam čuo izraziti želju da bi lječnik dr. Frane, dok ne dođe jednom

\footnotetext{
63 Naša sloga br. 19, 7. 5. 1885., 3.

64 Naša sloga br. 23, 4. 6. 1885., 2; br. 24, 11. 6. 1885., 1.

65 Naša sloga br. 24, 11. 6. 1885., 2; br. 25, 18. 6. 1885., 3.

66 Naša sloga br. 26, 25. 6. 1885., 3.
} 
stalno u ove strane, došao bar svako pol godine po koji tjedan. Dao Bog da bi se ta njihova vruća želja izpunila i da bi naskoro došao dan kad bi se u ovih predjelih stalno nastanio!”ㄱ Potkraj 1904. podijelilo je Općinsko zastupstvo za Volosko-Opatiju počasno građanstvo "veleučenom dr. Franu Mandiću u priznanje zasluga što ih je stekao za tu općinu" ${ }^{68}$. U srpnju 1908. car i kralj Franjo Josip Prvi dodijelio je dr. Franu Mandiću, liječniku i zdravstvenom savjetniku kod ravnateljstva Državnih željeznica u Trstu, naslov carskog savjetnika uz oprost od pristojbi. ${ }^{69}$

\section{OBitelj}

U braku s Marijom pl. Pichler s kojom se vjenčao 2r. lipnja I879. u Trstu, dr. Franjo Mandić imao je petero djece - Antu, Josipa, Mariju, Milenu i Danicu ${ }^{70}$. Sinove je poslao u hrvatske gimnazije u Rijeci i Zagrebu. Stariji je sin Ante (I88I. - I959.) nakon mature u gornjogradskoj gimnaziji u Zagrebu I899. studirao pravo u Grazu. Treći državni ispit i politički rigoroz na Pravnom fakultetu Sveučilišta u Grazu položio je i7. prosinca 1903. i odmah stupio u službu vježbenika na Zemaljskom sudu u Trstu ${ }^{71}$. Na čast doktora prava promaknut je 21. srpnja 1906. u Grazu. ${ }^{72}$ U braku s Olgom Nikolajevnom Stepenko, rođenom u Ukrajini, a zaposlenom u konzulatu Rusije u Trstu, imao je sina Olega (1906. - I979.). U veljači IgII. položio je odvjetnički ispit pred tršćanskom odvjetničkom komorom i u Vili Teuta u Opatiji otvorio odvjetničku pisarnicu ${ }^{73}$.

Mlađi sin Josip (I883. - 1959.) gimnaziju je započeo pohađati u Rijeci, nastavio u Zagrebu pa se vratio ponovno u hrvatsku gimnaziju na Sušaku. Još kao gimnazijalac iskazao se kao darovit skladatelj i pijanist. Prve poduke iz sviranja glasovira dobio je od svoje majke, a u Zagrebu se educirao kod Franje Serafina Vilhara-Kalskoga (I852. - I928.). U veljači I899. učenik šestog razreda gimnazije Josip Mandić uglazbio je Hrvatsku misu za mješoviti zbor. ${ }^{74}$ Djelo je tiskano u Leipzigu (čisti prihod od prodaje namijenjen je Družbi sv. Ćirila i Metoda za Istru), pohvalama ga je obasuo Matko Brajša Rašan (I859.

\footnotetext{
Naša sloga br. 26, 28. 6. 1894., 3.

Naša sloga br. 51, 22. 12. 1904., 4.

Naša sloga br. 31, 30. 7. 1908., 3.

Naša sloga br. 25, 23. 6. 1904., 3.

Naša sloga br. 57, 24. 12. 1903., 5 .

Naša sloga br. 30, 26. 7. 1906., 3.

Naša sloga br. 8, 23. 2. 1911., 2.

Naša sloga br. 5, 9. 2. 1899., 6.
} 
- 1934.). ${ }^{75}$ Na glazbeno-pjevačkoj zabavi priređenoj u ožujku igoo. u Rijeci u korist "siromašnih, a junačkih Bura koji se onako odvažno bore za slobodu domovine", izvođače je na glasoviru pratio, a i nešto izvornog odsvirao najmlađi sudionik koncerta, gimnazijalac Josip Mandić. ${ }^{76}$ Nakon mature na Sušaku Igor., započeo je studij medicine u Beču, a istodobno je studirao na Konzervatoriju. Na koncertu Slavenskoga pjevačkog društva u Trstu II. svibnja 1902. otpjevana je i pjesma Slaven i pjesma devetnaestogodišnjak slušatelja medicine Josipa Mandića na tekst dr. Dragana Lukeža (1869. - 1930.).77 $\mathrm{Na}$ koncertu s plesom Dalmatinskog skupa 20. ožujka 1903. u Trstu, uz poznata djela Smetane, Čajkovskog, Hatzea i Lisinskog, izvedeni su i fragmenti opere Petar Svačić Josipa Mandića. ${ }^{78}$ Osobitu pozornost kritike privukao je Mandićev Preludij na temelju narodnog napjeva Popuhnul je tihi vjetrić. Potkraj prosinca 1903. Josip Mandić, tada već student prava, osobno je u ljubljanskome Narodnom kazalištu uvježbavao pjevače, soliste i orkestar, pripremajući praizvedbu svoga novog djela, opere Petar Svačić za koju je libreto napisao dr. Trnoplesar Budisvoj (Karlo Lukež). ${ }^{79}$ Sama prazvedba I2. siječnja 1904. opisana je kao "hrvatsko slavlje u Ljubljani" i nije propušteno upozoriti da je autor dvadesetogodišnji Hrvat Josip Mandić, sin dr. Frana Mandića, liječnika u Trstu, rodom iz Rukavca u općini Kastav.$^{80}$ Nakon studija prava, završenog 1907. u Beču, vratio se u Trst. Uz rad u sudstvu, Josip Mandić bio je predsjednik Narodne radničke organizacije u Trstu te je putovao u Pulu ustanoviti njezinu podružnicu "da se sačuva naše radnike od talijanaških društava gdje ih uče prezirati svoju narodnost te sačuva narod od pogibeljnog socijalizma" ${ }^{11}$. Na glavnoj skupštini političkog društva Edinost u Trstu 24. studenoga 1907. izabran je za odbornika. ${ }^{82}$

Milena Mandić, najstarija kći dr. Mandića, nakon "vrlo dobrim" uspjehom položenoga prijamnog ispita, upisana je u rujnu i897. u prvi razred državne gimnazije u Trstu i tako postala "prva gimnazijalka na našem jugu" 33 . Početkom studenoga 1902. Marija Mandić iz Zavoda Notre dame de Sion u

\footnotetext{
Naša sloga br. 10, 16. 3. 1899., 3.

Naša sloga br. 14, 3. 4. 1900., 3.

Naša sloga br. 38, 23. 5. 1902., 3.

Naša sloga br. 9, 26. 2. 1903., 4.

Naša sloga br. 58, 31. 12. 1903., 5.

Naša sloga br. 3, 21. 1. 1904., 3.

Naša sloga br. 49, 26. 9. 1907., 2.

Naša sloga br. 58, 28. 11. 1907., 3.

Naša sloga br. 38, 23. 9. 1897., 2.
} 
Trstu, mlađa kći dr. Mandića, položila je s vrlo dobrim uspjehom ispit zrelosti iz francuskog i njemačkog na Ženskoj učiteljskoj školi za ručni rad u Gorici. ${ }^{84}$

\section{KRAJ}

Zadnje desetljeće života donijelo je dr. Franu Mandiću mnogo boli. Nakon višegodišnjeg bolovanja brat Matko umro je od leukemije i3. svibnja 1915. u Trstu i privremeno pokopan na tamošnjem groblju sv. Ane. Posljedna želja o prijenosu na groblje sv. Lucije u Kastvu ispunjena je tek 2. srpnja I922. Doživio je dr. Mandić paljenje i rušenje Slovenskoga narodnog doma u Trstu I3. srpnja I920. te istoga dana uništenje Hrvatskoga doma u Puli. Slijedilo je rušenje Narodnog doma u Sv. Ivanu pokraj Trsta (8. studenoga I92I.) te u Rojanu, također na periferiji Trsta (9. studenoga 192I).

Sina Antuna izbijanje Prvoga svjetskog rata zateklo je u Rusiji, a od srpnja 1915. povjeren mu je petrogradski ured Jugoslavenskog odbora utemeljenoga 30. travnja I915. u Parizu. Nastankom Države SHS te poslije Kraljevine Srba, Hrvata i Slovenaca vratio se u zemlju. Bio je odvjetnik u Opatiji. Mlađi sin Josip godine Prvoga svjetskoga rata proveo je u Švicarskoj, a I9I9. preselio je u Prag i tamo živio do smrti 5. listopada 1959. U listopadu 1923. kći Milena, udana za dr. Frana Brnčića (1876. - 1963.), rodom iz Brega, nećaka dr. Frane Mandića, promoviranog 25. svibnja 1903. u Grazu na čast doktora prava, preselila je s obitelji iz Trsta u Zagreb u kojem je suprug otvorio odvjetnički ured. 85,86

Samo tri mjeseca poslije u Trstu je, nakon duge i mučne bolesti, 2. siječnja 1924. umro dr. Fran Mandić. ${ }^{87}$ Njegovi posmrtni ostaci, prema još za života iskazanoj želji, prevezeni su u nedjelju 6. siječnja i924. u Kastav. ${ }^{88}$ Pri prolazu kroz Herpelj i Kozinu pozdravila su ga tamošnja pjevačka društva. Pokopan je na kastavskom groblju sv. Lucije između brata Matka i načelnika Jelušića. Okupili su se predstavnici Čitaonice, Sokola, Potpornog društva sv. Mihovila. Oproštajni govor održao je dr. Fran Jelušić, a nad grobom su pjevali članovi pjevačkog društva Istarska Vila.

\footnotetext{
Naša sloga br. 74, 13. 11. 1902., 9.

Naša sloga br. 22, 28. 5. 1903., 6.

Istarska riječ br. 39, 4. 10. 1923., 3.

Istarska riječ br. 1, 3. 1. 1924., 4.

Istarska riječ br. 2, 10. 1. 1924., 1.
} 


\section{ZAKLJUČAK}

Prošlo je gotovo puno stoljeće od smrti dr. Frana Mandića. Uvelike se promijenilo društveno ustrojstvo prostora u kojem je rođen i proveo život. Dio tih promjena proklijao je iz sjemena kakvo su svojim višedesetljetnim upornim i požrtvovnim radom sijali Dobrila, Spinčić, Laginja, Matko Mandić, a dr. Fran Mandić ih je svesrdno podupirao. Velike su promjene nastale i u medicini, pozivu kojim se dr. Mandić zdušno bavio. Mnogo više se zna o ljudskom organizmu, tehnologijske su mogućnosti pretraživanja i ranijeg prepoznavanja poremećaja puno bolje, a i terapija je usavršena. No i današnjim je liječnicima nužno toplo razumijevanje za ljudske boli i patnje jer bez toga ne mogu uspješno obavljati svoje svakodnevne zadaće. Ali ni danas, kao ni u doba dr. Frana Mandića, nije dovoljno biti liječnik u ordinaciji ili bolnici, treba naučiti razumijevati probleme pacijenta u obitelji i široj društvenoj zajednici. Liječnik mora poučavati, kao što su radile naše kolege. Stoga je bilo vrijedno rekonstruirati školovanje, cjelokupan rad i život dr. Frana Mandića za pouku studentu medicine i liječniku u 2r. stoljeću. 


\section{IZVORI I LITERATURA}

1. Istarska riječ br. 1, 3. 1. 1924., 4.

2. Istarska riječ br. 2, 10. 1. 1924., 1 .

3. Istarska riječ br. 39, 4. 10. 1923., 3.

4. Josip Janc. Naša sloga, br. 53, 31. 12. 1891., 3.

5. Laszowski, E. Ed. (1925), Znameniti i zaslužni Hrvati te pomena vrijedna lica u hrvatskoj povijesti od 925 - 1925., Zagreb, str. 172.

6. Mandić F. (1906), Malariatilgung im Gebiete der k.k.

Staatsbahndirektion Triest, Zeitschrift für Eisenbahnhigiene, 2 (6), 145-163.

7. Mandić F. Difteritis. Naša sloga br. 1, 1. 1. 1882., 1.

8. Mandić F. Difteritis. Naša sloga br. 3, 1.2. 1882., 1.

9. Mandić F. Poviest i razvitak zdravoslovja /Hygiene/. Naša sloga br. 1, 3 . 1. 1884., 1-2.

10. Mandić F. Poviest i razvitak zdravoslovja /Hygiene/. Naša sloga br. 2, 10. 1. 1884., 2.

11. Naša sloga br 34, 24. 8. 1893., 2.

12. Naša sloga br. 1, 1. 1. 1874., 1-2.

13. Naša sloga br. 1, 1. 1. 1883., 4.

14. Naša sloga br. 1, 1. 1. 1891., 3.

15. Naša sloga br. 1, 4. 1. 1906., 3.

16. Naša sloga br. 1, 7. 1. 1904., 2.

17. Naša sloga br. 2, 7. 1. 1909., 2.

18. Naša sloga br. 2, 8. 1. 1885., 3.

19. Naša sloga br. 2, 9. 1. 1890., 4.

20. Naša sloga br. 3, 17. 1. 1884., 1.

21. Naša sloga br. 3, 17. 1. 1886., 2-3.

22. Naša sloga br. 3, 21. 1. 1897., 3.
23. Naša sloga br. 3, 21. 1. 1904., 3.

24. Naša sloga br. 4, 16. 2. 1877., 4.

25. Naša sloga br. 4, 16. 2. 1882., 3.

26. Naša sloga br. 4, 16. 2. 1882., 3.

27. Naša sloga br. 4, 2. 2. 1899., 3.

28. Naša sloga br. 4, 28. 1. 1915., 3.

29. Naša sloga br. 5, 25. 1. 1909., 3.

30. Naša sloga br. 5, 9. 2. 1899., 6.

31. Naša sloga br. 6, 8. 2. 1906., 4.

32. Naša sloga br. 7, 1. 4. 1879., 1.

33. Naša sloga br. 7, 13. 2. 1908., 3.

34. Naša sloga br. 8, 19. 2. 1903., 8.

35. Naša sloga br. 8, 23. 2. 1911., 2.

36. Naša sloga br. 9, 25. 2. 1909., 2.

37. Naša sloga br. 9, 26. 2. 1903., 4.

38. Naša sloga br. 10, 16. 3. 1899., 3.

39. Naša sloga br. 10, 8. 3. 1900., 4.

40. Naša sloga br. 11, 1. 6. 1879, 3.

41. Naša sloga br. 13, 1. 7. 1874., 3.

42. Naša sloga br. 13, 1. 7. 1882., 2.

43. Naša sloga br. 13, 26. 3. 1885., 3.

44. Naša sloga br. 13, 26. 3. 1903., 7.

45. Naša sloga br. 13, 31. 3. 1898., 3.

46. Naša sloga br. 14, 16. 7. 1882., 4.

47. Naša sloga br. 14, 3. 4. 1900., 3.

48. Naša sloga br. 16, 16. 8. 1880., 3.

49. Naša sloga br. 16, 17. 4. 1884., 3.

50. Naša sloga br. 18, 5. 5. 1892., 3.

51. Naša sloga br. 19, 1. 10. 1878., 4.

52. Naša sloga br. 19, 2. 5. 1895., 2.

53. Naša sloga br. 19, 7. 5. 1885., 3.

54. Naša sloga br. 20, 15. 5. 1890., 2. 
55. Naša sloga br. 21, 1. 11. 1878., 4.

56. Naša sloga br. 21, 1. 11. 1880., 3.

57. Naša sloga br. 22, 28. 5. 1885., 2.

58. Naša sloga br. 22, 28. 5. 1903., 6.

59. Naša sloga br. 22, 8. 6. 1893., 3.

60. Naša sloga br. 23, 4. 6. 1885., 2.

61. Naša sloga br. 24, 11. 6. 1885., 1.

62. Naša sloga br. 24, 11. 6. 1885., 2.

63. Naša sloga br. 24, 15. 6. 1893., 3.

64. Naša sloga br. 24, 16. 12. 1877., 3.

65. Naša sloga br. 24, 16. 12. 1881., 3.

66. Naša sloga br. 25, 18. 6. 1885., 3 .

67. Naša sloga br. 25, 23. 6. 1892., 4 .

68. Naša sloga br. 25, 23. 6. 1904., 3 .

69. Naša sloga br. 26, 25. 6. 1885., 3.

70. Naša sloga br. 26, 26. 6. 1884., 6 .

71. Naša sloga br. 26, 28. 6. 1894., 3.

72. Naša sloga br. 29, 21. 7. 1887., 2.

73. Naša sloga br. 30, 26. 7. 1906., 3.

74. Naša sloga br. 30, 28. 7. 1887., 3.

75. Naša sloga br. 31, 30. 7. 1908., 3.

76. Naša sloga br. 31, 4. 8. 1887., 3.

77. Naša sloga br. 33, 17. 8. 1893., 2.

78. Naša sloga br. 35, 22. 8. 1895., 2.

79. Naša sloga br. 35, 30. 8. 1894., 3.

80. Naša sloga br. 36, 2. 9. 1889., 3.

81. Naša sloga br. 38, 23. 5. 1902., 3.

82. Naša sloga br. 38, 23. 9. 1897., 2.

83. Naša sloga br. 39, 23. 5. 1902., 4.

84. Naša sloga br. 40, 5. 10. 1893., 3.

85. Naša sloga br. 42, 15. 10. 1885., 1-2.

86. Naša sloga br. 42, 20. 10. 1887., 1.

87. Naša sloga br. 45, 28. 12. 1899., 3-4.
88. Naša sloga br. 49, 26. 9. 1907., 2.

89. Naša sloga br. 51, 17. 12. 1890., 3.

90. Naša sloga br. 51, 17. 12. 1890., 3.

91. Naša sloga br. 51, 20. 12. 1888., 1.

92. Naša sloga br. 51, 22. 12. 1904., 4.

93. Naša sloga br. 52, 24. 12. 1889., 3.

94. Naša sloga br. 52, 27. 12. 1888., 3.

95. Naša sloga br. 52, 29. 12. 1892., 2.

96. Naša sloga br. 53, 31. 12. 1891., 3.

97. Naša sloga br. 57, 24. 12. 1903., 5.

98. Naša sloga br. 58, 28. 11. 1907., 3.

99. Naša sloga br. 58, 29. 7. 1902., 4.

100. Naša sloga br. 58, 31. 12. 1903., 5.

101. Naša sloga br. 74, 13. 11. 1902., 9.

102. Naša sloga br. 74, 20. 9. 1901., 1.

103. Naša sloga br. 76, 27. 9. 1901., 3.

104. Naša sloga br. 85, 11. 12. 1900., 3.

105. Naša sloga br. 102, 31. 12. 1901., 4.

106. Obzor br. 2, 11. 3. 1879., 2.

107. Obzor br. 6, 9. 1. 1877., 3.

108. Primorac br. 32, 22. 4. 1874., 3.

109. Riječki novi list br. 9, 11. 1. 1912., 1.

110. Riječki novi list br. 42, 18. 2. 1912., 1.

111. Riječki novi list br. 57, 7. 3. 1912., $1-2$

112. Vučak I. (2009), Počeci hrvatske psihijatrije i dr. Dragutin Forenbacher. Liječničke novine br. 77, 15 .3. 2009., 66-70.

113. Vučak I. (2010), Otto Lenz i suzbijanje malarije na Brijunima. Liječničke novine br. 93, 15. 10. 2010., 56-59. 


\section{SAŽETAK}

Rođen u Istri, tada dijelu prostrane Austro-Ugarske Monarhije, Fran Mandić (I85I. - 1924.) završio je hrvatsku gimnaziju u Rijeci, a medicinu u Grazu i Pragu. Nakon promocije čitavu je liječničku karijeru proveo u Trstu, u njegovo doba glavnom gradu Austrijskog primorja. Nakon rada u bolnici, otvorio je vlastitu ordinaciju, a bio je i zdravstveni savjetnik Državnih željeznica. Čitavog je života, još od studentskih dana, sudjelovao u nastojanjima za postizanje jednakopravnosti hrvatskog naroda $u$ Istri. Uvjeren u važnost obrazovanja, ulagao je svoje vrijeme $i$ novac u otvaranje što većeg broja škola u Istri. Za zasluge u radu odlikovao ga je kralj, imenovan je počasnim građaninom Opatije, no najveće priznanje bio mu je ugled koji je uživao među pacijentima $i$ članovima njihovih obitelji.

Ključne riječi: medicina; povijest medicine; Istra; Hrvatska; Trst; Slovenija; Austro-Ugarska Monarhija; Italija 